\title{
Just Leave Us Alone: The Arab League and Human Rights
}

Vera van Hüllen

Forthcoming in:

Börzel, T. and van Hüllen, V. (2015) Governance Transfer by Regional Organizations: Patching Together a Global Script. Houndmills, Basingstoke: Palgrave Macmillan.

\section{INTRODUCTION}

Compared to a global trend towards governance transfer by regional organizations, the League of Arab States is clearly a latecomer in prescribing and promoting governance standards in its member states - and its efforts are more limited and weaker than in many other regional organizations (Börzel and Stapel in this volume). While the Arab League started to deal with selected human rights issues in the late 1960s, an Arab Charter on Humans Rights as the cornerstone of a regional human rights regime only entered into force in 2008 - much later than its American, European, and African counterparts. Continental organizations like the Organization of American States (OAS), the Council of Europe (CoE), and the Organization for African Unity (OAU), the predecessor of the African Union (AU), had developed regional human rights regimes early on. Moreover, many regional organizations worldwide turned to more actively prescribing and promoting standards related to human rights, democracy, the rule of law, and good governance in the 1990s. By contrast, only in the $21^{\text {st }}$ century has the Arab League begun to step up its efforts at governance transfer. It focuses on human rights as compared to democracy, the rule of law, or good governance, but even the catalogue of human rights adopted in 2004 falls short of international standards and the Arab Human Rights Committee has only a limited mandate for its promotion and protection. 
This empirical observation is not too surprising when one considers the 'persistence of authoritarianism' and the notoriously bad human rights performance of regimes in the region, backing the argument that a demand for governance transfer is often driven by an interest in 'locking in' democratic reforms in democratizing and newly democratic member states at the regional level (Börzel and van Hüllen in the Introduction to this volume). Accordingly, the evolution of governance transfer by regional organizations in Africa and more recently also in Asia is tightly linked to the democratization of individual member states (Börzel and van Hüllen in the Conclusion of this volume). In the Middle East and North Africa, however, member states of the Arab League have not yet experienced successful democratic transitions - Tunisia having been the last hopeful candidate in the wake of the 'Arab Spring' of 2011. From the first creation of a Permanent Arab Commission for Human Rights (PACHR) in 1968 to the adoption of the Arab Charter on Human Rights in 2004 and its subsequent ratification, there has not been a significant change in the 'democratic quality' of its member states that could account for the Arab League's increasing efforts at governance transfer. So why do authoritarian regimes engage in governance transfer at the regional level at all - and how can we account for changes in the intensity of their efforts over time?

The existence of a 'global script' for human rights as universally recognized governance standards can actually create a rational - rather than normative - demand among authoritarian regimes for governance transfer by their regional organization. Conforming to international (and domestic) expectations by creating regional provisions for governance transfer helps to fend off external attempts at interference in domestic and regional affairs and, at the same time, to remain in control of their design and application. This instrumental demand for 'pseudo'-governance transfer results in particularly weak institutions designed to deflect external pressure instead of effectively promoting and protecting governance standards in member states. 
The second section will start by sketching the evolution of the Arab League's efforts at governance transfer, covering its early engagement in human rights issues in the 1960s, the intensification of cooperation in selected human rights fields throughout the 1970s up until the 1990s, and the subsequent 'leap' in governance transfer in 2004. The third section then accounts for this evolution by tracing changes in the international and domestic environment since the 1960s. Various bodies of the United Nations (UN) and transnational human rights organizations actively promoted the evolving 'script' for human rights and their protection by regional organizations, pushing the Arab League to selectively engage in human rights issues. The subsequent intensification of regional cooperation on women and children's rights was facilitated by international human rights norms gaining prescriptive status in more and more member states and processes of political liberalization. However, changing security perceptions in the international community in the aftermath of the terrorist attacks on 11 September 2001 were crucial for bringing about the 2004 'surge' in the Arab League’s governance transfer. By drawing a connection between 'bad' governance, on the one hand, and a lack of socio-economic development and the risk of religious and ideological radicalization and terrorism, on the other hand, international actors like the United States (US), the European Union (EU) and its member states significantly increased their pressure on Arab regimes which in turn felt compelled to signal a more credible and comprehensive commitment to governance standards related to human rights, democracy, the rule of law, and good governance. The chapter concludes by discussing the ambivalent nature of 'pseudo'governance transfer by regional organizations and its potential impact on the stabilization or transformation of authoritarian regimes. While the Arab Spring brought a new dynamic of domestic change and regional cooperation to the Middle East and North Africa, recent initiatives such as the creation of an Arab Court of Human Rights suggest that the logic of governance transfer as a symbolic measure has not yet changed. 
The adoption of the Arab Charter on Human Rights in 2004 was considered a milestone for the development of a regional human rights regime in the Arab world. When the Charter entered into force in 2008, the Arab League had for the first time a comprehensive human rights catalogue and mechanism in place analogous to those of other 'continental' regional organizations such as the OAS, the CoE, and the AU. Compared to these organizations, the Arab League is clearly a latecomer with regard to the development of a regional human rights regime (Donnelly 2003). While it was the first regional 'arrangement' recognized by the UN, already founded in 1945 with the end of the Second World War, it took almost sixty years before member states adopted the Charter, decades after the other organizations put their human rights instruments in place. In addition, the content of the Charter falls short on universal standards and, especially compared to the Inter-American and the European regimes, the monitoring mechanism established is extremely weak, enforcement virtually non-existent. Given the 'persistence' of authoritarianism in the region since independence and well beyond the third wave of democratization, this lack of enthusiasm of Arab states to engage in governance transfer at the regional level is not too surprising. However, cooperation on human rights issues in the framework of the Arab League actually dates back to the 1960s. This raises the double question of why Arab states have engaged on human rights issues at all - and why, after the passing of forty years, they finally created the cornerstones of a regional human rights regime.

Whereas the CoE and the OAS included commitments to democracy and human rights in their founding treaties, there are until today no such references in the Alexandria Protocol (1944), the founding Pact of the League of Arab States (1945) or the Arab League’s major treaties (Cultural Treaty 1946, Treaty of Joint Defense and Economic Cooperation 1950). On the contrary, the Arab League's Pact declares the respective 'system of government' to be an internal affair of each member state and explicitly prohibits external attempts at regime change (article 8). In fact, 'the Arab League did not show any interest in human rights until 
1968' (An-Na'im 2001: 712), when it created the PACHR. Bringing together representatives of all member states, the PACHR was mandated to prepare Council decisions, facilitate dialogue and exchange between the member states, raise awareness on human rights issues, and coordinate the Arab League’s work in international fora (An-Na'im 2001: 712-713, AlAjaji 1990: 113-114). The activities of the PACHR have, however, been very limited. It has coordinated several initiatives to draft a human rights charter which all failed at different stages of the process during the 1970s and 1980s (Al-Ajaji 1990: 45-97, An-Na'im 2001: 713714). For the most part, it has monitored and denounced human rights violations by Israel in the occupied territories, making the Palestinian (human rights) question its main concern (AnNa'im 2001: 713, Al-Ajaji 1990: 116, Donnelly 2003: 144-145). The PACHR was clearly not concerned with governance transfer in terms of broadly prescribing and promoting human rights as governance standards in its member states. Rather, early cooperation on human rights within the Arab League was part of regional politics in the Arab-Israeli conflict. By contrast, the Arab League developed greater activity on a few, more narrowly defined human rights issues. Separate from the PACHR, it created specific bodies for coordinating cooperation on the rights of women, children, and the family, such as the Arab Women's Committee in 1971 (Al Maaitah et al. 2011). It even started to prescribe regional governance standards, for example in the 1983 Arab Declaration on the Rights of the Child (Amin AlMidani 2005) and in the 1994 Arab Declaration on the Family's Rights (Labadidy 1996). Especially in the 1990s and 2000s, the Arab League started to more actively promote these standards through conferences and action plans, building on the voluntary commitment of the participating member states and the 'soft' mechanisms of dialogue and exchange (AbdulHamid 2011; Al Maaitah et al. 2011).

In the late 1980s, the Arab League also re-launched its efforts at drafting a human rights charter. And indeed, the Arab League’s Council adopted a proposal put forward by the PACHR and the Arab League’s Legal Commission in its resolution no. 5437 on 15 September 
1994. This first Arab Charter on Human Rights was met with sharp criticism from international human rights and legal organizations and scholars for its shortcomings compared to universal standards enshrined in the various UN human rights conventions, for example with regard to religious freedoms and gender equality, and its weak monitoring and enforcement mechanisms (Rishmawi 2005: 362; An-Na'im 2001: 714). In the end, only few member states officially signed the Charter and it was never ratified (al-Jazy 1999).

The Arab League's activities in the field of women, children, and family rights continued and further intensified during the 2000s. Most prominently, however, the Arab League's summit adopted a revised draft of the Arab Charter on Human Rights in 2004 that came into effect in 2008 (Rishmawi 2010: 172). The PACHR thoroughly revised the 1994 draft between 2001 and 2004 based on consultations and recommendations by a group of experts. While considered a major improvement over the 1994 draft, it was still criticized for its continued shortcomings compared to international human rights standards (Forsythe 2009: 413-414, Rishmawi 2005: 364-376). The Charter only creates a weak regional human rights regime, both in substantive and procedural terms (Rehman 2010: 377-384). Nevertheless, it represents a milestone in the prescription and promotion of human rights standards by the Arab League vis-à-vis its member states. The Arab Human Rights Committee, operational since 2009, has to rely on reports by member states for monitoring their compliance with the Charter. It can only issue non-binding recommendations to member states, as the Charter does not foresee any complaint or enforcement mechanisms (Forsythe 2009: 414, Rishmawi 2010: 172-174). The 2004 Tunis Summit did not only adopt the Arab Charter on Human Rights, but also two declarations that broadened the Arab League’s commitment to governance standards to include democracy, the rule of law, and good governance. Neither of the declarations defined standards in detail, but they touched upon issues of political participation (democracy), independence of the judiciary (rule of law), freedom of expression (human rights), and good governance necessary for economic, social, and human development. In contrast to the Tunis 
Declaration, the Tunis Declaration on the Process of Reform and Modernization explicitly stated the objective to build democratic practice and protect human rights in the region. In general,

[t]here are some indications of a more progressive direction in Arab League developments on human rights, such as the 2005 Arab summit in Algiers, which called for increased attention to genuine democracy and equality for women in the public life of Arab countries. (Forsythe 2009: 415)

\section{GOVERNANCE TRANSFER AND AUTHORITARIAN SURVIVLAL POLITICS}

The Arab League has always had a purely authoritarian membership. Successively gaining independence, a variety of non-democratic regimes emerged in the region and the Arab League has been instrumental in consolidating sovereign Arab nation-states (Barnett 1998) and authoritarian rule. While the region has seen its fair share of regime changes, often forced through military coups, these have always been 'non-democratic transitions' (Schlumberger 2000), at least until the 'Arab Spring’. Especially in the early 1990s, the international community and scholars had high hopes for processes of democratization also in the Middle East and North Africa in the wake of the ‘third wave’ (Huntington 1991; Brynen, Korany, and Noble 1995). However, attempts at democratic transitions in, for example, Tunisia and Algeria failed, leading to more or less open authoritarian backlashes (Sadiki 2002, Volpi 2006). By the early 2000s, scholars started to highlight the 'persistence' or 'robustness' of authoritarianism (see for example Albrecht and Schlumberger 2004; Bellin 2004). Until today, indices for the quality of governance institutions such as the 'Freedom in the World' index by Freedom House, the World Bank’s 'Worldwide Governance Indicators', 'Polity IV', and others all attest the region an exceptionally bad performance with regard to human rights, democracy, the rule of law, and good governance. Even though Algeria and Lebanon have scored positively on the Polity score since 2004 and 2005 respectively, not one of the Arab 
League's member states even qualifies as an 'electoral democracy' according to Freedom House standards due to limitations to Political Rights and Civil Liberties.

Therefore, it is not surprising that the Arab League and its member states have been more reluctant to engage in governance transfer than regional organizations in most other regions, apart from maybe Asia. The Arab League represents a 'club of autocracies' par excellence where efforts at governance transfer have always been very limited, falling behind global standards it terms of their content and instruments, making sure to not place additional constraints on its member states. But why, then, did the Arab League develop a regional human rights policy at all - and why did its member states finally agree to adopt and ratify the Arab Charter on Human Rights in 2004? Neither the early human rights policy nor the recent 'surge' in governance transfer, including a high level commitment to human rights, democracy, the rule of law, and good governance were driven by processes of democratization that could have created an interest in using the Arab League to lock in democratic reforms.

Changes in the international and domestic context generated a demand for governance transfer among authoritarian member states that had little to do with a genuine interest in protecting and promoting governance standards related to human rights, democracy, the rule of law, and good governance. The (selective) institutionalization of (selected) standards and instruments, especially in the field of human rights, allowed the member states of the Arab League to signal both domestic constituencies and international community that they were part of a ‘modern’ regional organization in line with a global script in order to (re)gain legitimacy and stabilize their rule.

\section{The Beginning in the 1960s}

The creation of the PACHR in 1968 came in response to a number of human rights activities within the UN framework since the mid 1960s (Al-Ajaji 1990: 111, An-Na'im 2001: 712). The UN General Assembly had decided in 1965 to make 1968 the Year of Human Rights in 
order to celebrate 20 years of the Universal Declaration of Human Rights (UDHR). At the same time, the UN Economic and Social Council started to engage more actively with regional organizations, which led to the creation of regional commissions, including the Economic and Social Commission for Western Asia (ESCWA) in 1973. It invited the Arab League, among others, to participate in the preparations for these celebrations, including the first International Human Rights Conference to be held in Teheran in 1968, and the work of the UN Human Rights Commission more generally (al-Jazy 1999). The Arab League created two working committees in 1965 and 1966 to coordinate its position in and cooperation with UN bodies in preparation for the celebrations in 1968. In addition, the UN Human Rights Commission discussed a proposal to create a network of regional human rights commissions following the American and (Western) European examples. The Arab League clearly rejected the idea in 1966, arguing that regional human rights regimes should be institutionalized within the framework of regional intergovernmental organizations rather than the UN system (AlAjaji 1990: 112).

Efforts at strengthening the UN human rights regime during the 1960s - the two Covenants had just been adopted in 1966 - thus created a demand among the Arab League’s member states to institutionalize cooperation on human rights issues at the regional level in the PACHR in order to facilitate their engagement at the global level and fend off interferences in regional matters through the UN system. Participating in the global human rights policy became the appropriate thing to do for UN member states and their regional organizations. The UN Human Rights Commission even went a step further by actively promoting the creation of regional human rights regimes, working on a script for governance transfer by regional organizations in the field of human rights.

The creation of the PACHR was a tactical concession to international expectations, trying to deflect the 'threat' of a human rights commission for the Arab world imposed through the UN system that might not be under the direct and sole control of the Arab League's member 
states. The institutional design was clearly not modelled after the human rights regimes established within the OAS and the CoE, neither prescribing a set of detailed standards nor creating effective mechanisms for their promotion and protection. While not fulfilling the function of human rights commissions vis-à-vis their member states as in Europe and the Americas, the PACHR proved useful to Arab states in their struggle for the Palestinian cause. From the beginning, the work of the PACHR focused almost exclusively on Palestinian (human) rights, trying to mobilize the international community against Israel on charges of human rights violations within the UN system (An-Na'im 2001: 713, Al-Ajaji 1990: 116). Having been defeated by Israel in the 1967 Six-Day-War, the Arab League developed a 'growing awareness of the importance of human rights as a useful political weapon, particularly vis a vis [sic] Israeli human rights violations in the occupied territories' (Al-Ajaji 1990: 112). While the creation of the PACHR marked the beginning of the Arab League's human rights policy, it was not intended as a means of governance transfer seeking to prescribe and promote governance standards in its member states.

\section{Increasing Activity since the 1970s}

The activities of the PACHR and the Arab League on broader human rights issues remained very limited during the 1970s and 1980s. On the one hand, Arab states continued to mobilize the international community against Israel (al-Jazy 1999: 215, Donnelly 2003: 144-145, Forsythe 2009: 412). On the other hand, efforts to adopt a human rights charter elaborated by the PACHR failed repeatedly (An-Na'im 2001: 713-714). However, the Arab League’s activities in the fields of women, children, and family rights intensified in line with the global agenda. The creation of the Arab Women’s Committee in the early 1970s was again directly related to preparations for a UN conference, as the First World Conference on Women was organized in 1975, leading to the adoption of the UN Convention on the Elimination of All Forms of Discrimination against Women in 1979. Similarly, the Arab League’s Declaration on Children's Rights in 1983 coincided with negotiations for the UN Convention on the 
Rights of the Child (1989) starting in the early 1980s. The Convention, adopted in 1989, is one of the few UN human rights instruments quickly and almost universally ratified in the Arab word, next to the 1965 International Convention on the Elimination of All Forms of Racial Discrimination (UNDP 2014). The regional agenda was clearly driven by global initiatives, creating a demand for the Arab League to actively participate in the global human rights discourse. However, these early efforts at a regional human rights policy were limited in both scope and intensity, covering only selected human rights issues and refraining from a more detailed prescription of standards or mechanisms for their promotion and protection beyond a certain coordination of national efforts at the regional level, clearly limiting their importance for governance transfer. For example, the Arab League never prominently picked up on the topic of torture, and the UN Convention against Torture and Other Cruel, Inhuman or Degrading Treatment or Punishment initially received only few ratifications following its adoption in 1984 in the Middle East and North Africa.

In addition to UN initiatives setting the regional agenda, human rights started to slowly gain prescriptive status in more and more of the Arab League's member states during the 1980s (Gränzer 1999). By 1990, almost all of the Arab League’s member states had ratified the UN Anti-Discrimination Convention and at least half of them also the two Covenants of 1966. Signing up to international human rights standards facilitated a corresponding regional policy, potentially driven by the demand to signal a more credible commitment to the international community, especially as compliance improved only slowly.

This dynamic intensified in the 1990s, without, however, leading to a qualitative change in the Arab League’s governance transfer. After the end of the Cold War, several UN conferences stressed the claim, now more universally accepted than ever, of international human rights norms, including the World Summit for Children in 1990, the World Conference on Human Rights in Vienna in 1995 and the Fourth World Conference on Women in Beijing in 1995. Again, many of the Arab League's initiatives are directly linked to these meetings, for 
example preparation of and follow up to the Beijing conference in cooperation with the ESCWA (ESCWA 1995). At the end of the 1990s, more than half of the Arab League's member states had finally ratified major international human rights instruments, such as the UN Conventions on Women and Torture.

This change in the international environment also spurred the first adoption of the Arab Charter on Human Rights in 1994. Member states finally agreed to reconsider the PACHR's draft in the early 1990s (An-Na'im 2001: 713). In 1990, they had already adopted the Cairo Declaration on Human Rights in Islam in the framework of the Organization of the Islamic Conference. The Cairo Declaration was clearly essentialist in its religious foundation of individual human rights (Brems 2001: 259-266), but while the Arab Charter on Human Rights failed to meet international human rights standards, it was still framed in universalist terms, taking the Cairo Declaration as a point of reference but not using it as a template (al-Jazy 1999). The agreement in the Arab League’s Council on the draft Charter was certainly facilitated by processes of political liberalization in a number of its member states during the late 1980s and early 1990s. However, none of these processes led to successful democratic transitions and the window of opportunity had closed again by the mid-1990s, with the civil war and military rule in Algeria and the authoritarian backlash of the Ben Ali regime in Tunisia. During the negotiations, Egypt had justified the Charter 'as a regional shield against international pressures on Arab states in the field of human rights’ (An-Na'im 2001: 715), clearly suggesting a rationalist demand for its adoption, but severe criticism of the Charter's content by international human rights organizations might have further dampened the enthusiasm of the Arab League’s member states for its ratification.

\section{A Major Leap in the 2000s?}

The interactive dynamic between the regional and the global level in the field of women and children's rights carried on into the 2000s. Beyond the 'normative power' of the international human rights regime, changes in the international and domestic environment further increased 
the (rationalist) demand for governance transfer by the Arab League in the early 2000s, leading to the revision, adoption, and ultimately the ratification of the Arab Charter on Human Rights and the Arab League's commitment to democracy, the rule of law, and good governance as basic governance standards beyond human rights.

This ‘surge' towards governance transfer by the Arab League in 2004 was certainly not due to a sudden belief in the normative value of democracy, human rights, the rule of law, and good governance as universal standards for governance. Looking at the Arab League's activities more closely suggests that its recent efforts should be understood as symbolic action rather than attempts at effectively promoting and protecting governance standards in the region. Even though the final draft of the Arab Charter on Human Rights was brought closer to global standards, its content still falls behind internationally recognised, 'universal' norms, for example with regard to gender equality, the death penalty, and the right to derogations under emergency law (Forsythe 2009: 413-414; Rishmawi 2005: 364-376)

What is clear is that the 2004 Charter reflects largely the degree of acceptance of international human rights law and standards by certain Arab states, as demonstrated, for example, by their reservations to UN human rights treaties. (Rishmawi 2010: 172)

While the Arab League sought to include international human rights experts in the process of revising the 1994 draft, their recommendations were ultimately discarded by the member states (Rishmawi 2010: 170, Forsythe 2009: 413-414). In addition, the Arab Human Rights Committee represents an extremely weak mechanism for supervising and enforcing member states’ compliance with the Charter by international standards. Except for the fight against corruption, in the Arab League’s logic part of its internal security agenda, the commitments made in Tunis in 2004 with regard to democracy, the rule of law, and good governance have not been translated into regional action. Rather, these measures were meant to establish a regional counter-discourse in order to insulate member states against criticism of 'bad 
governance' by transnational human rights organizations and the international community and fend off external efforts at governance transfer.

So, if authoritarian regimes felt that these measures did not hurt them, why did they not adopt them before? By the beginning of the $21^{\text {st }}$ century, regimes in the Middle East and North Africa came under increasing pressure from above and from below that challenged their stability and survival. Especially the events of 11 September 2001 dramatically changed the international environment for authoritarian regimes in the region (Albrecht and Schlumberger 2004). In addition, social tensions increased in many countries, undermining the legitimacy of incumbent rulers. The series of four Arab Human Development Reports (AHDR) published by the United Nations Development Programme (UNDP) in 2003-2006 symbolized the increased international attention paid to problems of 'bad' governance as the root cause for a lack of socio-economic and human development and ultimately religious radicalization, terrorism, and increasing instability in the region and beyond. Had the creation of the PACHR been sufficient to fend off interferences through the UN system in the 1960s, the Arab League and its member states now had to signal more credibly their commitment to being 'good' members of the international community. Provisions for promoting and protecting human rights through by the Arab League in line with the global script for governance transfer by regional organizations thus became an attractive option for authoritarian rulers for boosting their image as modern and well governed regimes.

International democracy promotion efforts in the region had intensified during the 1990s, but remained rather 'soft' and limited (van Hüllen and Stahn 2009). In the aftermath of the terrorist attacks on 11 September 2001, international democracy promotion became inextricably linked to international security concerns and the 'war on terror' (Carothers 2003). Not least the US-led interventions in Afghanistan (2001) and Iraq (2003) showed the vulnerability of authoritarian regimes to external regime change in the name of international security. Even though these interventions were highly disputed for their international 
legitimacy, the international community converged on the consensus that the emerging postconflict order had to be in line with Western notions of 'good' governance including democracy and the rule of law. Governments of a number of Arab states were in an awkward position between popular protest against foreign interventions and supporting the US. As allies in the 'war on terror' they could count on the lenience of Western partners when placing their priority on (internal) security rather than the respect for human rights and fundamental freedoms. At the same time, however, the international community identified 'bad' governance as one of the root causes for radicalization and terrorism. The Middle East and North Africa suddenly became the focus of international democracy promotion efforts, both bilaterally and through a number of regional initiatives driven by external actors, such as the G8 Broader Middle East and North Africa (BMENA) initiative, the US Middle East Partnership Initiative (MEPI), and in the framework of the EU's neighborhood policy (van Hüllen and Stahn 2009).

While the impact of international democracy promotion efforts has been limited and observers have often charged international actors with inconsistency and hypocrisy, authoritarian regimes were compelled to at least formally strengthen their commitment to universal values in order to remain in good standing in the international community. Adopting standards and instruments for governance transfer at the regional level that at least formally resembled those of other regional organizations around the world, member states of the Arab League could signal this commitment to the international community in order to (re)gain international legitimacy. Borrowing from the global script for 'good' regional organizations allowed them to conform to international demands and fend off external interferences in internal affairs. In fact, the Arab League's then Secretary-General Amr Moussa had been successful in framing the Charter as part of his ambitions to modernize the Arab League (Rishmawi 2005: 362). Similar to the early 1990s, a number of regimes experienced a political opening in the early 2000s, for example over the course of successions in Morocco (1999), Jordan (1999), and 
Syria (2000). The new Moroccan King Muhammad VI, for example, made 'human development' one of his priorities in 2000, pursuing a comprehensive reform agenda for modernizing the country at least partially in line with a 'Western' governance script (Desrues and Moyano 2001). Again, legal reforms and governmental programs did not lead to democratic transitions anywhere in the region, but even some countries of the Gulf, especially Kuwait and Bahrain felt compelled to sign up to major international human rights instruments in the late 1990s and early 2000s. However, the onset of the 'war on terror' saw a backlash for civil and political rights between 2001 and 2003, not least captured by Freedom House, for example through the adoption of restrictive media and NGO laws, before the international community felt increasingly compelled to stress the need to respect human rights while fighting terrorism. The adoption of the Arab Charter on Human Rights and the other declarations adopted at the Tunis Summit in 2004 came just in time to brush up the Arab regimes tarnished reputation internationally, but also in response to increasing social tensions and political demands at the domestic level.

Even before the 'Arab Spring’ of 2011, regimes in many countries had faced protests that indicated a growing dissatisfaction of the people with their rulers. Socio-economic difficulties severely compromised the output legitimacy of those authoritarian regimes that were not able to compensate the lack of economic development through oil rents. They undermined popular support for the regimes as they failed to hold up their end of social pact promising socioeconomic development instead of political participation (Heydemann 2007). Especially many of the North African countries had difficulties in generating sufficient economic growth to compensate for the social implications of structural reforms in the 1980s (Layachi 2000).

\section{CONCLUSIONS}

The evolution of the Arab League's activities in the field of human rights and beyond shows that it can be rational for authoritarian regimes to engage in governance transfer at the regional level on the basis of supply and demand factors identified in the introduction to this 
volume (Börzel and van Hüllen in this volume). The supply of a 'global' script for human rights as governance standards and provisions for governance transfer by regional organizations, actively promoted by UN actors and transnational human rights activists, raised expectations regarding the 'appropriate' behavior of states and regional organizations regarding human rights and, in the 2000s, increased pressure by the international community. Against this background, authoritarian regimes in the Middle East and North Africa developed a demand for efforts at governance transfer by the Arab League in order to conform to these expectations and thus fend off external interferences into domestic and regional affairs and signal a commitment to governance reforms to domestic constituents. There are no indicators, however, for a normative demand or a genuine, rationalist interest of Arab states in governance transfer as an effective problem-solving strategy. Neither driven by a demand for locking in democratic reforms in member states nor for curbing negative externalities of 'bad' governance in the region, the Arab League engages in 'pseudo'governance transfer, that is provisions that look like governance transfer, but are not intended to be effective in prescribing, promoting, and protecting governance standards in its member states (cf. Russo in this volume for the CIS).

Nevertheless, the case of the Arab League highlights the importance of changes in international norms and the emergence of a 'global script' that clearly distinguish the field of human rights from other governance standards, such as democracy and the rule of law, where governance transfer by regional organizations has developed in a much more decentralized process (Börzel and Stapel in this volume). However, it is also clear that the diffusion of human rights protection is not about simply 'downloading' a template or emulating the practice of other continental organizations such as the OAS and the CoE but about 'localizing' institutions in line with the specific regional demand (Acharya and Johnston 2007). Despite the exchange of ideas in various fora at the different levels, the Arab League's member states ultimately shaped the design of regional provisions according to their 
preferences, as reflected in the Arab League’s comparatively weak human rights regime, suggesting an interest in symbolic action rather than effective institutions.

Governance transfer by the Arab League has been designed to deflect or mitigate the 'normative power' of the global human rights regime and not reinforce its impact on domestic change. The Arab League’s provisions might not only be ineffective in promoting compliance with international governance standards. If these tactical concessions and façade reforms satisfy the expectations of the international community, external pressure to translate formal commitments and institutions into behavioral change at the domestic level might even lessen, as international actors might be quite happy about their ability to legitimize their own cooperation with authoritarian regimes. By contrast, the 'spiral model' suggests that even these formal institutional changes will, in the long run, have a positive impact as incumbent regimes get rhetorically entrapped on a path 'from commitment to compliance’ (Risse, Ropp, and Sikkink 2013). Whether or not the diffusion of governance transfer to regional organizations with an authoritarian membership will be a 'success' or a 'failure' for the promotion of governance standards worldwide, will ultimately depend on its impact as leading to 'better' or 'worse' governance.

Beyond changes in the international environment, the 'Arab Spring' in early 2011 also promised to change the domestic conditions for governance transfer by the Arab League. A wave of popular protest challenged authoritarian rulers throughout the region and initiated a new dynamic, with regard to both domestic political reforms and to regional cooperation. Initially, hopes were high for democratic transitions in a number of countries that would radically alter the political landscape in the region and the composition of the Arab League's membership, possibly giving a boost to governance transfer by the Arab League in order to effectively lock in democratic reforms. They were, however, soon dashed as most regimes managed to stay in power, adopting only marginal political reforms, and transition processes in Egypt, Libya, and Yemen went awry, leaving only Tunisia as a candidate for democratic 
regime change. However, Arab governments still paid increased attention to human rights and governance issues at the regional level in light of the Arab Spring: by November 2011, the proposal for an Arab Court of Human Rights, first tabled in the early 1970s, was put forward by the King of Bahrain and in 2014, the Arab heads of state and government adopted a draft statute at their Summit in Kuwait. Even the Gulf-Cooperation Council (GCC), bringing together six of the least politically liberalized countries in the Arab world, started to discuss human rights issues at the regional level. The form and content of these initiatives, however, suggests a continued demand for symbolic measures to alleviate domestic and international pressure rather than measures that effectively support political reforms for the liberalization and modernization, if not democratization, of incumbent regimes in line with a global governance script. In line with the Arab League’s previous initiatives for governance transfer, the proposal for a human rights court 'falls well short of regional and international human rights standards' (FIDH and ICI 2014) and the GCC's human rights office, established in 2012, is primarily mandated to document human rights policies and 'achievements' in the GCC and its member states (GCC 2012). It remains to be seen in how far political reforms below the threshold of democratic regime change will be sufficient to allow the 'spiral model' to work (more) successfully in the future (van Hüllen 2013) and generate a greater demand for governance transfer by the Arab League. 